\title{
Trading offspring for survival: high duckweed cover decreases reproductive potential and stimulates elongation in the submerged macrophyte Chara globularis Thuillier
}

\author{
Stijn Van Onsem (D) Ludwig Triest
}

Received: 10 October 2020/Revised: 14 March 2021/Accepted: 19 March 2021/Published online: 9 May 2021

(C) The Author(s) 2021

\begin{abstract}
Compact blankets of free-floating plants generate stressful aquatic environments. The response of submerged macrophytes remains largely elusive. Will they rush toward the light or rather speed up reproductive efforts and escape using propagules - the macrophyte equivalent of lifeboats? We studied the effects of complete duckweed (Lemna minor) cover on growth and reproductive fitness of macroalga Chara globularis in a pond mesocosm experiment. $C$. globularis growing in Lemna-covered plots lost biomass and developed longer internodes, indicating an elongative reflex to escape stress. Densities of reproductive organs per biomass unit evolved positively in open plots and negatively in covered plots, suggesting a trade-off between reproductive effort and vegetative elongation. Reproductive potential correlated significantly with incident radiation. Lemna cover, however, did not affect oospore rain-at least within the limited time span of propagule trapping. $C$. globularis thus displayed an ability to modify
\end{abstract}

Handling editor: André Padial

Electronic supplementary material The online version of this article (https://doi.org/10.1007/s10750-021-04577-y) contains supplementary material, which is available to authorized users.

S. Van Onsem $(\bowtie) \cdot$ L. Triest

Plant Biology and Nature Management, Department of Biology, Vrije Universiteit Brussel, Brussels, Belgium e-mail: svonsem@gmail.com phenology in response to floating plant stress, allocating resources to internodes instead of gametangia. Nevertheless, duckweed dominance clearly suppressed the overall reproductive performance of $C$. globularis. The regenerative capacity of many submerged macrophytes will likely suffer from increased floating plant dominance due to global warmingunless efforts are made to reduce nutrient levels in vulnerable waterbodies.

Keywords Pond C Charophyta - Antheridia . Oogonia $\cdot$ Propagules $\cdot$ Lemna

\section{Introduction}

Submerged macrophytes occupy a niche that easily turns hostile following anthropogenic nutrient loading. Under eutrophic conditions, the interplay between biotic interactions, the abiotic environment and climate favors a dominance of either submerged macrophytes, phytoplankton, or free-floating plants (Scheffer et al., 1993, 2003; Phillips et al., 2016; Van Onsem \& Triest, 2018). In many wind-sheltered ponds and ditches, increased nutrient availability ultimately benefits lemnids (duckweeds; fam. Araceae), which consequently outcompete submerged aquatic vegetation as well as phytoplankton for light (Portielje and Roijackers, 1995; Scheffer et al., 2003; 
Feuchtmayr et al., 2009). Moreover, global warming can be expected to stimulate floating plant dominance in the near future (Feuchtmayr et al., 2009; Peeters et al., 2013) and undermine viability of submerged aquatic vegetation (Netten et al., 2010)—aggravating preexisting trends toward an increased ratio of floating over submerged plants (Kim \& Nishihiro, 2020).

Progressive stability of lemnid mats can have detrimental effects on submerged macrophytes. By blocking sunlight and creating hypoxic conditions, lemnids potentially transform aquatic habitats into underwater deserts (Portielje and Roijackers, 1995; Janse and Van Puijenbroek, 1998). Even without or prior to complete loss of submerged macrophytes, the underlying vegetation could experience disturbed growth rates and modified reproductive patterns (Janes et al., 1996; Li et al., 2015). For most submerged taxa, the direction, extent and flexibility of the reproductive response to increased stress have not been mapped. If resource allocation is rigid, a stressful environment likely hampers final propagule output. On the contrary, macrophytes displaying high trait plasticity (DeWitt et al., 1998; Sultan, 2000) could either react to stress or disturbance by increasing reproductive investment (Garbey et al., 2004; Puijalon et al., 2008; Sato et al., 2014), or adapt non-regenerative growth to force a release from the stressor, e.g., by elongating shoots (Blindow et al., 2003; Asaeda et al., 2007; Lu et al., 2013; Schneider et al., 2015; Chen et al., 2020) or boosting allelopathic defenses (Hilt and Gross, 2008). Under restricted resource availability, a trade-off between non-reproductive growth and vegetative or sexual propagation would logically occur in plastic species (Boedeltje et al., 2008; Van Drunen and Dorken, 2012; Eckert et al., 2016).

Here, the potential of submerged macrophytes to control reproductive resource allocation in function of an environmental change, more specifically floating plant nuisance, was experimentally investigated. We studied the effect of complete Lemna minor L. cover on growth and reproductive output of Chara globularis Thuillier. C. globularis is a common, eutrophication-tolerant, monoecious macroalga, and like other members of Charophyceae (stoneworts) depends to a large extent on sexually produced oospores for regeneration (Bonis and Grillas, 2002). We installed mesocosms around C. globularis growing in a shallow pond and hypothesized a Lemna treatment would affect both non-reproductive growth and densities of sex organs (male antheridia and female oogonia), thus altering the potential reproductive output. Production and release of oospores was quantified using traps positioned close to the sediment (Van Onsem et al., 2018), and was expected to be favored by a suitable light regime.

\section{Materials and methods}

Study site

The experiment was conducted in summer 2012 in the Denis pond $\left(50^{\circ} 49^{\prime} 44^{\prime \prime} \mathrm{N}, 4^{\circ} 25^{\prime} 51^{\prime \prime} \mathrm{E}\right)$, a shallow (0.5 $\mathrm{m}$ deep) artificial waterbody with a relatively small surface area ( 0.33 ha) situated in the Woluwe Park at the eastside of the Brussels-Capital Region (Fig. 1). During construction of the 68-ha-sized park at the end of the 19th century, Denis pond was excavated just upstream of another, larger pond (1.75 ha), connected through an overflow. Denis pond is mainly fed by groundwater seepage, and has a retention time of around 220 days. The riparian zone consists of vertical, wooden embankments and lacks emergent macrophytes. The pond's perimeter mainly consists of hilly grass lawns.

The Denis pond had been subject to phytoplankton dominance in the past and therefore was biomanipulated between 2006 and 2007, combining complete water drawdown, fish removal and pike addition. Although biomanipulation successfully restored clearwater conditions, no macrophytes were observed in the period 2007-2010 (no data are available for 2011). Grazing peaks of herbivorous waterfowl probably hindered development of submerged aquatic vegetation, since oospore densities in the propagule bank were not a limiting factor (Van Onsem \& Triest, 2018). Early in the growth season of 2012, meadows of C. globularis did appear, together with Ceratophyllum demersum L. (frequent) and Potamogeton pusillus L. (occasional). L. minor covered part of the southern and western edges of the pond. No fish were observed during the course of the study.

Mesocosm set-up and environmental monitoring

We used remodeled plastic bins as mesocosm plots. The circular bins (diameter: $0.48 \mathrm{~m}$ ) were modified by removing the bottom and cutting out parts from the 


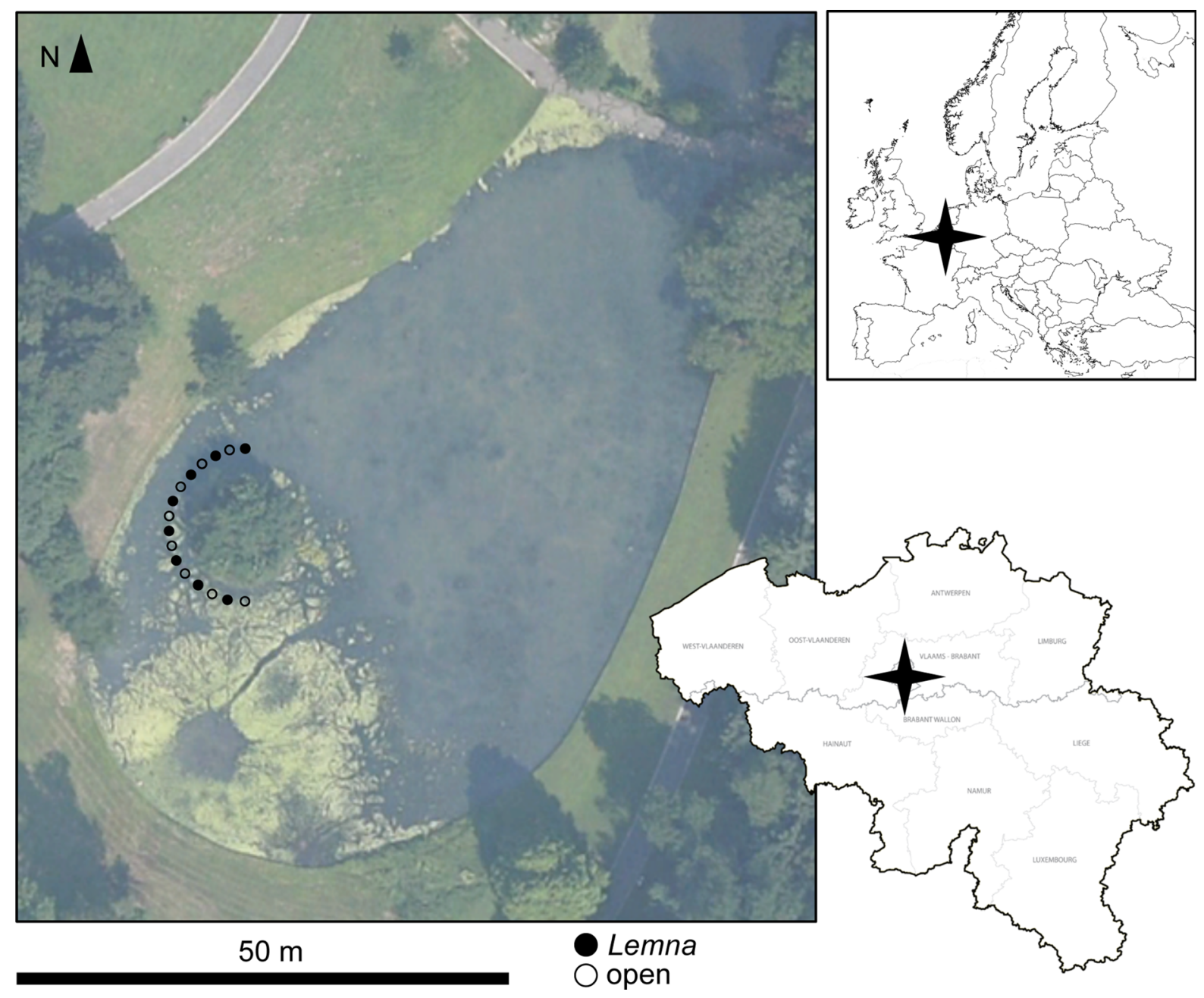

Fig. 1 Mesocosm set-up in Denis pond, Brussels-Capital Region (Belgium). Plots were installed in a shallow zone along a man-made island. Images from Google Earth

lower half, creating an inverted crown with four spikes that served as plot anchors. On August 10th, sixteen plots were gently inserted in the sediment on top of healthy $C$. globularis beds growing in a shallow zone situated along an artificial island (Fig. 1; AppendixSupplementary Material 1). The mesocosms were installed in a sickle-shaped, linear fashion around the island. Distance between the islands' shore and the plots was around two to three meters. Measured from the sediment, height of the mesocosms was $0.45 \mathrm{~m}$. The choice for this particular set-up was driven by a visual estimation of macroalgal fitness, which seemed to deteriorate in deeper, more exposed parts of the pond. On top of the mesocosms, we attached bird netting to protect L. minor and C. globularis from herbivory and disturbance.

In the middle of each plot, we carefully pinned a propagule trap (Van Onsem et al., 2018) in the sediment underneath C. globularis (Appendix-Supplementary Material 2). Propagule traps consisted of commercially available, circular and meshed plastic baskets (height: $10.2 \mathrm{~cm}$ ) fabricated for potting aquatic plants, and had a diameter of $11.8 \mathrm{~cm}$ at the top (surface area $0.0109 \mathrm{~m}^{2}$ ). The inner side of the pots was coated with a glued $180 \mu \mathrm{m}$ polyester fabric, suited for capturing oospores of $C$. globularis (Haas, 1994; Boszke and Bociagg, 2010). To secure the propagule traps, the baskets were pinned in the sediment using 24-cm-long tent pegs, fitted on both 
sides. C. globularis thalli were gently repositioned over the collector.

Following mesocosm planting, C. globularis was allowed to acclimatize for two days before the initiation of the duckweed treatment on August 12th (day 1). In an alternating fashion, plots were covered with L. minor (100\% cover, collected within Pond Denis; $n=8)$ or left open $(n=8)$. The experiment lasted for 40 days. We made sure that the initial duckweed cover remained constant (either 0 in control plots or $100 \%$ in treatment plots) throughout the experiment, by occasionally removing or adding some Lemna fronds where needed.

To follow-up environmental changes, physical and physical-chemical variables as well as nutrient concentrations were measured in the water column on three occasions (day 13: August 24th, day 21: September 1st, day 44: September 24th). Oxygen, $\mathrm{pH}$ and temperature were measured on the field using a WTW portable multimeter after collection of $1 \mathrm{~L}$ of mesocosm water, from which a filtered $\left(\mathrm{NO}_{\mathrm{x}}-\right.$ nitrate and nitrite; $\mathrm{NH}_{4}{ }^{+}$-ammonium; and SRP-soluble reactive phosphorus) and unfiltered (TP - total phosphorus; Chl $a$-chlorophyll $a$ ) subsample was taken for subsequent spectrophotometric analysis (APHA, 1995). Photosynthetically active radiation (PAR, as PPFFR - photosynthetic photon flux fluence rate) was measured using an underwater radiation sensor (LICOR LI-193), held just under the water surface. In parallel, abiotic variables were analyzed for pond water collected in the vicinity of the plots.

Biomass sampling and relative growth rate

A first biomass sample (day 1) was collected outside of the plots, to mimic the initial status of $C$. globularis, by gathering the vegetation within an area of $15 \times 15 \mathrm{~cm}$. On day 20 (half-way) and day 40 (final), biomass was sampled within the mesocosms using an area of $10 \times 10 \mathrm{~cm}$ on opposite sides of the centrally positioned, overgrown propagule traps. During collection of $C$. globularis, fresh material was divided into two separate fractions: the upper $15 \mathrm{~cm}$ and the remaining undergrowth (bottom fraction).

We divided biomass samples based on the assumption that the Lemna treatment would initiate biometric or reproductive responses mainly within the top layer, which contains new outgrowth of thalli. Biomass samples were kept in sealed plastic bags and stored at $4^{\circ} \mathrm{C}$ in attendance of processing. At the time of biomass sampling, we also recorded the relative volume of the water column taken up by $C$. globularis (PVI-percent volume infested), a measure of plant abundance.

After analysis of vegetative and reproductive traits (see next section), the combined (total) sampled biomass from top and sub $C$. globularis layers was oven-dried at $70^{\circ} \mathrm{C}$ for $72 \mathrm{~h}$ and subsequently weighted. The relative growth rate (RGR) of $C$. globularis total biomass was calculated using the formula $\left[\ln \left(\right.\right.$ biomass $\left._{\mathrm{t}=\mathrm{b}}\right)-\ln \left(\right.$ biomass $\left.\left._{\mathrm{t}=\mathrm{a}}\right)\right] /(\mathrm{b}-\mathrm{a})$.

Vegetative and reproductive thallus traits

Relative to algal standards, Charophyceae species have complex multicellular and branched morphologies. The thallus of $C$. globularis consists of slender, corticated internodes connecting whorls, which originate from the nodes. The whorls carry paired sexual organs (female oogonia and male antheridia; see Appendix-Supplementary Material 3). Within biomass samples originating from the top $15 \mathrm{~cm}$ of the $C$. globularis stands, we analyzed both vegetative and reproductive features:

- Internodal length (vegetative), i.e., stretched distance between whorls. Per sample, 25 internodes were measured with a ruler, avoiding both apical and basal (i.e., first of a branch) internodes.

- Gametangial density (reproductive), i.e., density of sexual organs per biomass unit. Reproductive patterns were investigated by scanning $65 \pm 15$ (mostly 70) randomly selected whorls per plot sample with a stereoscopic microscope. The exact whorl number depended on the density of the $C$. globularis meadow in the plots. We counted antheridia and oogonia separately, because within reproductive pairs antheridia tend to mature first (so-called protandry; Casanova, 1994; Calero et al., 2015, 2017), potentially affecting detectability. Gametangia present on terminal whorls were too delicate and immature to be quantified accurately and were not included. Since delineation of successive developmental stages lay outside the scope of this study, we implemented relaxed definitions of female structures, terming unfertilized gametangia and fertilized oosporangia (Soulié-Märsche and García, 2015) 'oogonia'. 
Oospores-including both ripening, uncalcified, blackened oospheres and calcified gyrogoniteswere omitted from trend analyses, because they readily detached, involving a risk of underestimation. After processing, the subsamples were ovendried at $70^{\circ} \mathrm{C}$ during $72 \mathrm{~h}$. Reproductive effort was expressed as the number of oogonia or antheridia per gram dry weight within the upper $15 \mathrm{~cm}$ layer.

- Gametangial abundance (reproductive). We determined the total number of gametangia present per unit area $\left(\mathrm{n} \mathrm{m}^{-2}\right)$ in the upper layer at final harvest—combining information on biomass and reproduction-and its relation with the light climate (PAR) during the study period.

\section{Oospore rain}

At the end of the experiment, propagule traps were retrieved and collected deposits were transferred to falcon tubes stored at $4^{\circ} \mathrm{C}$. The settled material collected with the propagule traps was spread out in a petri dish and scanned with a stereoscopic microscope to count the number of oospores (see Appendix-Supplementary Material 3). Oospore rain is presented as the rate of deposition per unit area per day ( $\mathrm{n} \mathrm{m}^{-2}$ day $^{-1}$; Van Onsem et al., 2018).

\section{Statistical analysis}

The treatment effect on environmental conditions and C. globularis relative growth rate was analyzed using Mann-Whitney $U$-tests, since data did not conform to assumptions of parametric statistics.

Evolutions of $C$. globularis total biomass, internode length and gametangia density were analyzed using repeated-measures ANOVA with additional fixed treatment factor to study effects of Lemna cover (STATISTICA 13.2). Assumptions of homoscedasticity for the treatment factor (Levene's test) and sphericity for within-subject effects (Mauchly's test) were checked prior to each ANOVA analysis. We allowed moderate deviations from normality in subgroups, visually estimated based on histograms. Violations of sphericity were resolved by adjusting the degrees of freedom using the Greenhouse-Geisser correction. For internodal length, a nested term (plot nested in treatment) was added to the repeatedmeasures structure, to account for multiple measures within the same plot. Since in the case of internodal length Levene's test indicated heteroscedasticity between treatments within sampling campaigns, data were $\log _{10}$-transformed-with success. Significant ANOVA's were decomposed using post hoc Tukey's HSD tests.

Spearman's rank-order correlations were applied to establish the relation between light climate and final reproductive investment (visualized using non-parametric LOESS plots). The effect of Lemna cover and total biomass of $C$. globularis (averaged over the experimental period) on oospore rain was verified using a generalized linear model (identity link; package glmmTMB; Magnusson et al., 2017; R3.2.0).

\section{Results}

Environmental conditions

The abiotic conditions during the experiment are summarized in Table 1, Appendix-Supplementary Material 4 and Appendix-Supplementary Material 5. Oxygen levels and $\mathrm{pH}$ were greatly elevated in open plots (on average $20.69 \mathrm{mg} \mathrm{L}^{-1}$ and 8.99 , respectively), and significantly higher compared to Lemnacovered mesocosms (average of $11.59 \mathrm{mg} \mathrm{L}^{-1}$ and 8.14, respectively; $\mathrm{O}_{2}$ concentration: $\mathrm{U}=76$, $P<0.0001 ; \quad \mathrm{pH}: \quad \mathrm{U}=118, \quad P<0.001 ; \quad n=24$; Table 1; Appendix-Supplementary Material 5). Similarly, floating plant cover significantly lowered PAR ( $\mathrm{U}=78, P<0.0001 ; n=24)$, on average with $85 \%$ (Table 1; Appendix-Supplementary Material 5). Planktonic Chl $a$ and nutrient concentrations did not differ between treatments.

Biomass and relative growth rate

Total biomass of $C$. globularis evolved negatively under Lemna but stayed relatively stable in uncovered plots (Fig. 2). This diverging trend in submerged macrophyte abundance was significant (Fig. 2; Table 3). At the end of the study, the whole $C$. globularis stand weighed on average $588 \pm 89 \mathrm{SD}$ $\mathrm{g}\left(\right.$ dry weight-dw) $\mathrm{m}^{-2}$ in open plots versus $160 \pm 113 \mathrm{SD} \mathrm{g}(\mathrm{dw}) \mathrm{m}^{-2}$ in closed plots (Table 2). The difference was also reflected in contrasting PVI values $(\mathrm{U}=59, P<0.0001)$ : during the course of the experiment, $C$. globularis largely filled the whole 
Table 1 Abiotic variables measured in open (control, $n=8$ ) and Lemna (treatment, $n=8$ ) plots on three occasions

\begin{tabular}{|c|c|c|c|c|c|c|c|c|c|c|}
\hline \multirow[t]{2}{*}{ Variable } & \multirow[t]{2}{*}{ Unit } & \multicolumn{3}{|l|}{ Open } & \multicolumn{3}{|l|}{ Lemna } & \multicolumn{3}{|l|}{ Pond } \\
\hline & & 24-Aug & 1-Sep & 24-Sep & 24-Aug & 1-Sep & 24-Sep & 24-Aug & 1-Sep & 24-Sep \\
\hline \multirow[t]{2}{*}{$\mathrm{pH}$} & & 9.26 & 9.31 & 8.40 & 8.31 & 8.60 & 7.53 & 8.77 & 9.09 & 7.28 \\
\hline & & 0.22 & 0.61 & 0.90 & 0.51 & 0.66 & 0.27 & - & - & - \\
\hline \multirow[t]{2}{*}{$\mathrm{T}$} & ${ }^{\circ} \mathrm{C}$ & 25.9 & 21.3 & 16.0 & 25.8 & 20.5 & 15.7 & 25.7 & 20.9 & 15.0 \\
\hline & & 0.5 & 1.3 & 0.4 & 0.5 & 0.9 & 0.3 & - & - & - \\
\hline \multirow[t]{2}{*}{$\mathrm{O}_{2}$ (con.) } & $\mathrm{mg} \mathrm{L}^{-1}$ & 20.8 & 23.3 & 18.0 & 11.2 & 14.9 & 8.7 & 14.1 & 20.0 & 5.1 \\
\hline & & 2.0 & 6.3 & 8.3 & 0.8 & 6.4 & 3.3 & - & - & - \\
\hline \multirow[t]{2}{*}{$\mathrm{O}_{2}$ (sat.) } & $\%$ & 255 & 262 & 187 & 138 & 166 & 90 & 174 & 222 & 51 \\
\hline & & 25 & 77 & 86 & 10 & 74 & 34 & - & - & - \\
\hline \multirow[t]{2}{*}{ PAR } & $\mu \mathrm{mol} \mathrm{m}{ }^{-2} \mathrm{~s}^{-1}$ & 606 & 655 & 112 & 72 & 59 & 19 & - & - & - \\
\hline & & 371 & 261 & 67 & 38 & 39 & 9 & - & - & - \\
\hline \multirow[t]{2}{*}{ Chl $a$} & $\mu \mathrm{g} \mathrm{L}^{-1}$ & 6.0 & 1.2 & 7.2 & 2.2 & 5.7 & 12.3 & 4.0 & 7.3 & 4.9 \\
\hline & & 3.2 & 0.4 & 5.5 & 0.8 & 3.1 & 7.5 & - & - & - \\
\hline \multirow[t]{2}{*}{ Depth } & $\mathrm{m}$ & 0.42 & 0.42 & 0.42 & 0.43 & 0.43 & 0.43 & - & - & - \\
\hline & & 0.03 & 0.03 & 0.03 & 0.04 & 0.04 & 0.04 & - & - & - \\
\hline \multirow[t]{2}{*}{$\mathrm{NO}_{\mathrm{x}}$} & $\operatorname{mg~N~L}{ }^{-1}$ & 0.025 & 0.042 & 0.104 & 0.018 & 0.031 & 0.098 & 0.024 & 0.029 & 0.157 \\
\hline & & 0.039 & 0.036 & 0.038 & 0.009 & 0.016 & 0.040 & - & - & - \\
\hline \multirow[t]{2}{*}{$\mathrm{NH}_{4}^{+}$} & $\mathrm{mg} \mathrm{N} \mathrm{L}^{-1}$ & 0.017 & 0.015 & 0.314 & 0.018 & 0.024 & 0.407 & 0.011 & 0.015 & 0.799 \\
\hline & & 0.006 & 0.002 & 0.268 & 0.007 & 0.004 & 0.248 & - & - & - \\
\hline \multirow[t]{2}{*}{ DIN } & $\mathrm{mg} \mathrm{N} \mathrm{L}^{-1}$ & 0.039 & 0.057 & 0.418 & 0.035 & 0.053 & 0.505 & 0.034 & 0.044 & 0.956 \\
\hline & & 0.043 & 0.036 & 0.298 & 0.014 & 0.020 & 0.286 & - & - & - \\
\hline \multirow[t]{2}{*}{$\mathrm{TP}$} & $\operatorname{mg~P~L}{ }^{-1}$ & 0.364 & 1.640 & 1.460 & 0.651 & 1.602 & 1.546 & 0.451 & 1.593 & 1.517 \\
\hline & & 0.058 & 0.516 & 0.079 & 0.939 & 0.125 & 0.090 & - & - & - \\
\hline \multirow[t]{2}{*}{ SRP } & $\mathrm{mg} \mathrm{P} \mathrm{L}^{-1}$ & 0.030 & 0.021 & 0.016 & 0.026 & 0.025 & 0.016 & 0.041 & 0.015 & 0.015 \\
\hline & & 0.004 & 0.005 & 0.004 & 0.004 & 0.003 & 0.002 & - & - & - \\
\hline
\end{tabular}

Pond data are included for comparison $(n=3$ ). Mean (upper figure) \pm SD (lower figure). DIN—dissolved inorganic nitrogen (sum of nitrates, nitrites and ammonium). 24-Aug: day 13, 1-Sep: day 21, 24-Sep: day 44 of the experiment

water column in all open plots (Appendix-Supplementary Material 5), whereas only the three southernmost Lemna mesocosms attained PVI levels of $100 \%$.

Within all time slots, RGR in terms of biomass was mostly negative and significantly lower for the Lemna treatment (d20-d1: $\mathrm{U}=1, P<0.01 ; \mathrm{d} 40-\mathrm{d} 20: \mathrm{U}=8$, $P<0.05 ;$ d40-d1: $\mathrm{U}=0, \quad P=0 ; n=8$; Fig. 3 ). Average RGR over the entire interval equaled $0.004 \pm 0.005 \mathrm{SD} \mathrm{g} \mathrm{g}^{-1} \mathrm{day}^{-1}$ for the open treatment compared to $-0.035 \pm 0.023 \mathrm{SD} \mathrm{g} \mathrm{g}^{-1}$ day $^{-1}$ within the Lemna plots.
Internodal length

Both midway and at the end of the experiment, thalli of C. globularis had developed significantly longer internodes in Lemna plots compared to open plots (F $=50.5, P<0.001$; Table 3; Fig. 6). After 40 days, the average internodal distance in Lemna plots reached $35.1 \pm 16.0 \mathrm{SD} \mathrm{mm}$, compared to $24.7 \pm 11.4 \mathrm{SD} \mathrm{mm}$ in open mesocosms (Table 2).

Gametangial density and abundance

Density of both male and female gametangia increased in open plots and decreased in closed plots relative to the starting situation (Fig. 4). The effect of Lemna cover was significant (antheridia: $F=39.9$, 
Fig. 2 Evolution of total biomass of $C$. globularis in open and Lemna-covered mesocosm plots $(n=8$ per treatment and campaign). Different letters correspond to significant differences over all box plots

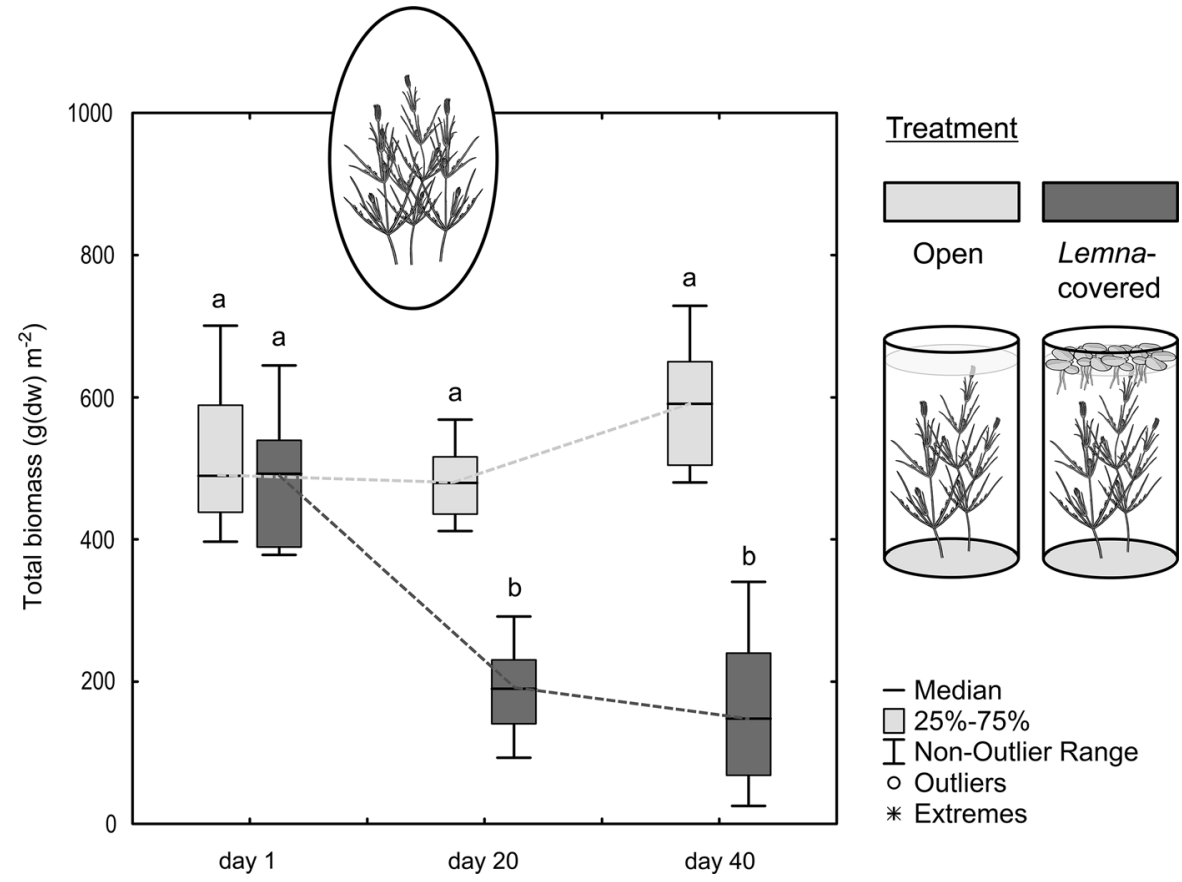

Table 2 Reproductive and growth characteristics of Chara globularis in response to treatments

\begin{tabular}{|c|c|c|c|c|c|c|c|}
\hline \multirow[t]{2}{*}{ Variable } & \multirow[t]{2}{*}{ Unit } & \multicolumn{3}{|l|}{ Open } & \multicolumn{3}{|l|}{ Lemna } \\
\hline & & Day 1 & Day 20 & Day 40 & Day 1 & Day 20 & Day 40 \\
\hline \multirow[t]{2}{*}{ Antheridia density ${ }^{a}$} & \multirow[t]{2}{*}{$\mathrm{n} g(\mathrm{dw})^{-1}$} & 679 & 1122 & 1841 & 804 & 345 & 163 \\
\hline & & 650 & 399 & 318 & 365 & 219 & 188 \\
\hline \multirow[t]{2}{*}{ Oogonia density $^{\mathrm{a}}$} & \multirow[t]{2}{*}{$\mathrm{ng}(\mathrm{dw})^{-1}$} & 887 & 1192 & 2023 & 1193 & 279 & 179 \\
\hline & & 580 & 443 & 429 & 280 & 255 & 260 \\
\hline \multirow[t]{2}{*}{ Oospore density $^{\mathrm{a}}$} & \multirow[t]{2}{*}{$\mathrm{n} g(\mathrm{dw})^{-1}$} & 60 & 0 & 75 & 119 & 42 & 1 \\
\hline & & 78 & 1 & 88 & 156 & 59 & 2 \\
\hline \multirow[t]{2}{*}{ Biomass upper layer ${ }^{\mathrm{a}}$} & \multirow[t]{2}{*}{$g(d w) m^{-2}$} & 70 & 175 & 309 & 48 & 37 & 59 \\
\hline & & 28 & 52 & 73 & 30 & 27 & 60 \\
\hline \multirow[t]{2}{*}{ Biomass total $^{\mathrm{b}}$} & \multirow[t]{2}{*}{$\mathrm{g}(\mathrm{dw}) \mathrm{m}^{-2}$} & 516 & 480 & 588 & 483 & 188 & 160 \\
\hline & & 107 & 53 & 89 & 95 & 64 & 113 \\
\hline \multirow[t]{2}{*}{ Antheridia abundance ${ }^{\mathrm{a}}$} & \multirow[t]{2}{*}{$\mathrm{n} \mathrm{m}^{-2}$} & $4.4 \mathrm{E}+04$ & $1.9 \mathrm{E}+05$ & $5.7 \mathrm{E}+05$ & $3.9 \mathrm{E}+04$ & $1.1 \mathrm{E}+04$ & $1.6 \mathrm{E}+04$ \\
\hline & & $3.2 \mathrm{E}+04$ & $6.1 \mathrm{E}+04$ & $1.8 \mathrm{E}+05$ & $3.0 \mathrm{E}+04$ & $1.2 \mathrm{E}+04$ & $3.2 \mathrm{E}+04$ \\
\hline \multirow[t]{2}{*}{ Oogonia abundance $^{\mathrm{a}}$} & \multirow[t]{2}{*}{$\mathrm{n} \mathrm{m}^{-2}$} & $6.1 \mathrm{E}+04$ & $2.0 \mathrm{E}+05$ & $6.3 \mathrm{E}+05$ & $5.7 \mathrm{E}+04$ & $1.2 \mathrm{E}+04$ & $2.3 \mathrm{E}+04$ \\
\hline & & $3.3 \mathrm{E}+04$ & $6.4 \mathrm{E}+04$ & $2.2 \mathrm{E}+05$ & $3.6 \mathrm{E}+04$ & $1.7 \mathrm{E}+04$ & $4.2 \mathrm{E}+04$ \\
\hline \multirow[t]{2}{*}{ Oospore abundance ${ }^{\mathrm{a}}$} & \multirow[t]{2}{*}{$\mathrm{n} \mathrm{m}^{-2}$} & $5.7 \mathrm{E}+03$ & $3.5 \mathrm{E}+01$ & $2.5 \mathrm{E}+04$ & $5.6 \mathrm{E}+03$ & $1.3 \mathrm{E}+03$ & $8.4 \mathrm{E}+01$ \\
\hline & & $9.6 \mathrm{E}+03$ & $9.8 \mathrm{E}+01$ & $2.9 \mathrm{E}+04$ & $6.4 \mathrm{E}+03$ & $2.2 \mathrm{E}+03$ & $2.4 \mathrm{E}+02$ \\
\hline \multirow[t]{2}{*}{ Internodal length $^{\mathrm{a}}$} & \multirow[t]{2}{*}{$\mathrm{mm}$} & 36.1 & 41.2 & 24.7 & 34.8 & 50.5 & 35.1 \\
\hline & & 14.6 & 16.9 & 11.4 & 13.6 & 19.4 & 16.0 \\
\hline
\end{tabular}

Mean (upper figure) \pm SD (lower figure)

${ }^{\mathrm{a}}$ Upper layer $(15 \mathrm{~cm})$ of the meadow

${ }^{\mathrm{b}}$ Complete stand 


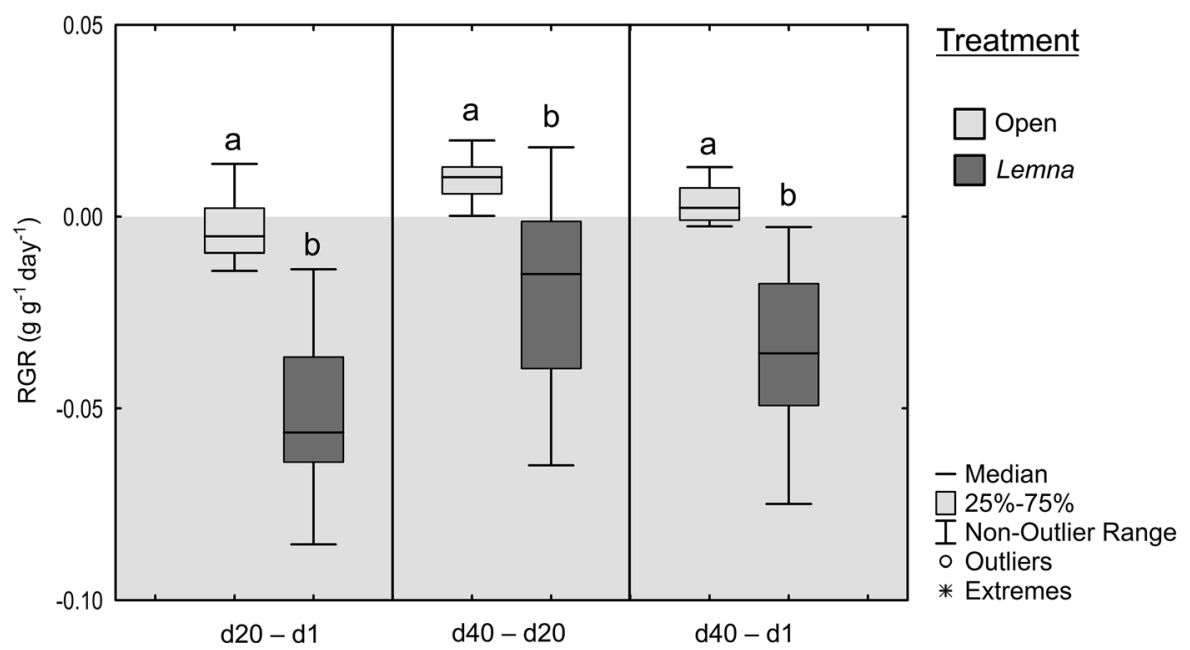

Fig. 3 Relative growth rate of $C$. globularis in terms of biomass change in first, second and entire interval $(n=8$ per treatment and campaign). The filled area below 0 indicates a

$P<0.001$; oogonia: $\mathrm{F}=35.2, P<0.001$; Table 3). Unstressed, antheridia and oogonia reached densities of $1841 \pm 318 \mathrm{SD} \mathrm{g}(\mathrm{dw})^{-1}$ and $2023 \pm 429 \mathrm{SD}$ $\mathrm{g}(\mathrm{dw})^{-1}$, respectively (Table 2 ). On the other hand, Lemna shading lowered densities to $163 \pm 188$ SD antheridia $\mathrm{g}(\mathrm{dw})^{-1}$ and $179 \pm 260 \mathrm{SD}$ oogonia $\mathrm{g}(\mathrm{dw})^{-1}$ at the end of the experiment.

Light conditions during the experiment correlated significantly positively with total gametangia abundance at final harvest (antheridia: $r_{\mathrm{s}}=0.79$, $P<0.001$; oogonia: $\mathrm{r}_{\mathrm{s}}=0.83, P<0.001$; Fig. 5).

\section{Oospore rain}

Under Lemna, the rate of oospore deposition averaged $672 \pm 510 \mathrm{SD} \mathrm{n} \mathrm{m}^{-2}$ day $^{-1}$, against $911 \pm 621 \mathrm{SD} \mathrm{n}$ $\mathrm{m}^{-2}$ day $^{-1}$ in open plots (Fig. 7). The treatment effect (Lemna versus open) on oospore rain was marginally insignificant (glm estimate: $2929 \pm 1659$ SE, $P=0.077$ ). We found no significant relation between oospore rain and vegetation biomass (glm estimate: $3.6 \pm 3.1 \mathrm{SE}, P=0.243$; Fig. 7 ).

\section{Discussion}

Mats of floating plants can be a recurrent, persistent symptom of eutrophication in sheltered temperate waterbodies (Portielje and Roijackers, 1995; Scheffer et al., 2003; Boedeltje et al., 2005; Feuchtmayr et al., negative biomass evolution. Different letters correspond to significant differences within an interval. $d=$ day

2009). Our results demonstrate that stability of underlying $C$. globularis meadows can be directly affected by floating vegetation mats through decreased biomass and PVI, even in superficial $(<0.5 \mathrm{~m}$ deep) waters. A drop in biomass and presumed concomitant fitness might impair the ability of $C$. globularis to architecturally dominate the water column, and could also reduce the effectiveness of the macroalgae to inhibit autotrophic competitors through allelopathy (Berger and Schagerl, 2004; Blindow et al., 2014).

Strongly elevated $\mathrm{pH}$ values and oversaturated dissolved $\mathrm{O}_{2}$ levels encountered in open mesocosms are indicative of enhanced photosynthetic activity relative to Lemna-covered plots, which was not explained by phytoplankton Chl $a$ abundance and therefore likely related to $C$. globularis productivity. Indeed, relative growth rate was mostly positive for open plots, while Lemna generally inhibited biomass expansion. Underneath the duckweed, positive growth rates and high oxygen concentrations were temporarily achieved only in the southern-most mesocosm plots, where exposure to sunlight was highest. Restricted charophycean growth as a result of light limitation or plant cover has been described by Schaible et al. (2012) and Sato et al. (2014), while Blindow et al. (2003) and Li et al. (2015) did not observe reduced biomass, indicating differential responses in function of specific circumstances and species identity. 
Table 3 Results of repeated-measures ANOVA with fixed (treatment) factor
$S S$ sum of squares, $d f$ degrees of freedom, $M S$ mean sum of squares

\begin{tabular}{|c|c|c|c|c|c|}
\hline & SS & Df & MS & $F$ & $P$ \\
\hline \multicolumn{6}{|l|}{ Biomass } \\
\hline Intercept & $7,783,090$ & 1 & $7,783,090$ & 660.0 & $<0.001$ \\
\hline Treatment & 755,990 & 1 & 755,990 & 64.1 & $<0.001$ \\
\hline Error & 165,104 & 14 & 11,793 & & \\
\hline Date & 238,888 & 2 & 119,444 & 19.5 & $<0.001$ \\
\hline Date*Treatment & 321,474 & 2 & 160,737 & 26.2 & $<0.001$ \\
\hline Error & 171,775 & 28 & 6135 & & \\
\hline \multicolumn{6}{|l|}{ Antheridia density } \\
\hline Intercept & $32,680,360$ & 1 & $32,680,360$ & 179.6 & $<0.001$ \\
\hline Treatment & $7,253,487$ & 1 & $7,253,487$ & 39.9 & $<0.001$ \\
\hline Error & $2,546,769$ & 14 & 181,912 & & \\
\hline Date & 738,511 & 2 & 369,256 & 2.8 & \\
\hline Date*Treatment & $6,518,251$ & 2 & $3,259,125$ & 24.3 & $<0.001$ \\
\hline Error & $3,752,145$ & 28 & 134,005 & & \\
\hline \multicolumn{6}{|l|}{ Oogonia density } \\
\hline Intercept & $44,122,241$ & 1 & $44,122,241$ & 193.7 & $<0.001$ \\
\hline Treatment & $8,023,364$ & 1 & $8,023,364$ & 35.2 & $<0.001$ \\
\hline Error & $3,189,201$ & 14 & 227,800 & & \\
\hline Date & $1,222,982$ & 2 & 611,491 & 5.2 & $<0.05$ \\
\hline Date*Treatment & $9,312,234$ & 2 & $4,656,117$ & 39.5 & $<0.001$ \\
\hline Error & $3,303,019$ & 28 & 117,965 & & \\
\hline \multicolumn{6}{|l|}{ Internodal length } \\
\hline Intercept & 2768 & 1 & 2767.7 & $82,538.1$ & $<0.001$ \\
\hline Treatment & 2 & 1 & 1.7 & 50.5 & $<0.001$ \\
\hline Plot (Treatment) & 4 & 14 & 0.3 & 8.3 & $<0.001$ \\
\hline Error & 13 & 384 & 0.0 & & \\
\hline Date & 8 & 2 & 4.0 & 134.2 & $<0.001$ \\
\hline Date*Treatment & 1 & 2 & 0.6 & 21.7 & $<0.001$ \\
\hline Date*Plot (Treatment) & 6 & 26 & 0.2 & 7.0 & $<0.001$ \\
\hline Error & 23 & 768 & 0.0 & & \\
\hline
\end{tabular}

In conjunction with decreased biomass, C. globularis developed longer thallus internodes in reaction to shading. Shoot elongation is a frequent phenomenon in Chara and Nitella species experiencing light limitation and directs biomass toward light (Casanova, 1994; Blindow et al., 2003; Asaeda et al., 2007; Schaible et al., 2012). Li et al. (2015) did, however, not observe shoot elongation in C. globularis in response to Eichhornia crassipes (Mart.) Solms cover, which was attributed to shading tolerance. In fact, the shoot response of Chara spp. on irradiance might depend on a combination of intensity and direction of incident light, in which internodal cells receiving abundant lateral light grow shorter in comparison to thalli packed in dense or periphyton-covered beds (Schneider et al., 2015).

In the current study, an interaction with the available space in the water column cannot be ruled out. During the experiment, C. globularis generally reached the surface under open conditions, against only a minor fraction of Lemna-stressed stands. Shortening of internodes could be an adaptive response initiated near the water surface to optimize the use of space and maximize resource acquisition and reproduction. Near the water surface, a change of habit might also be a defense against damage inflicted by high PAR or UVB irradiation (Rubio et al., 2015), though we did not observe signs of reduced vitality 


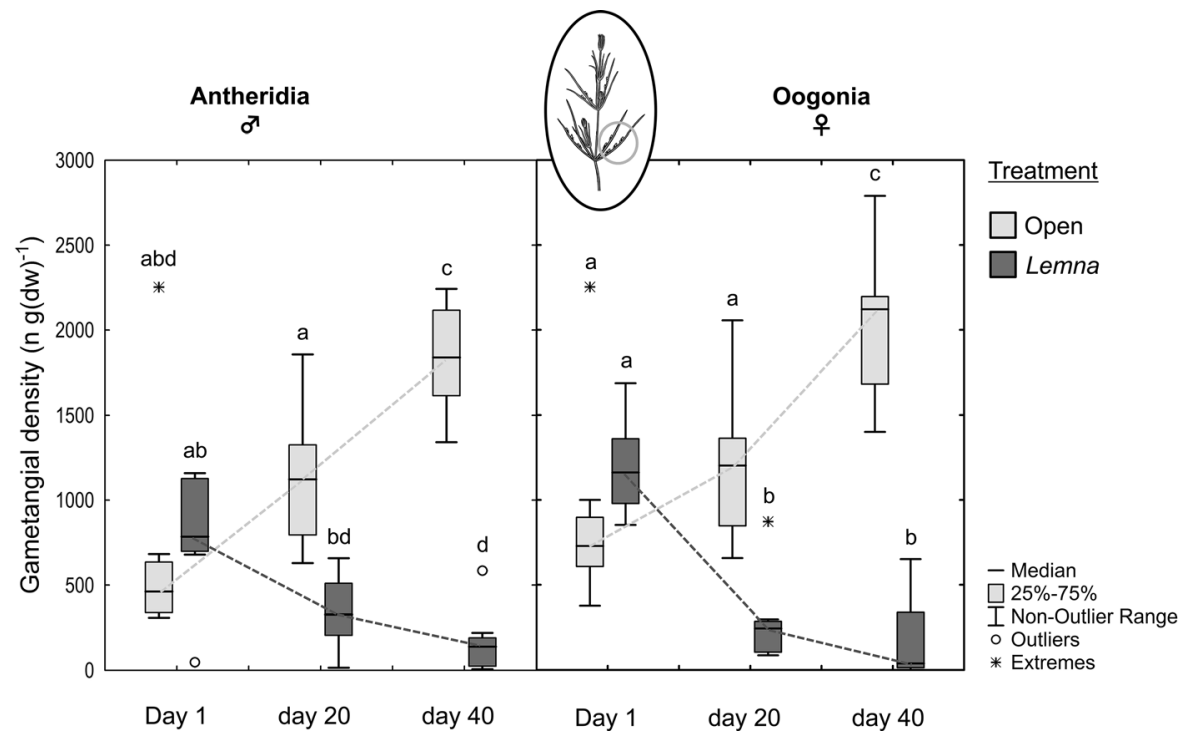

Fig. 4 Evolution of gametangial density (left: antheridia; right: oogonia) in C. globularis in open and Lemna-covered mesocosm plots ( $n=8$ per treatment and campaign). Different letters correspond to significant differences over all box plots

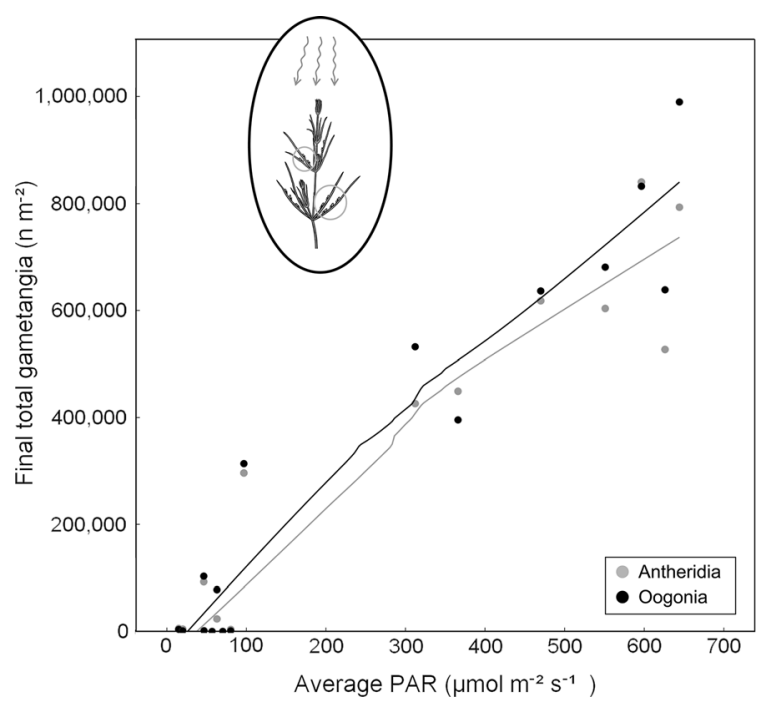

Fig. 5 Relation between incident PAR (Photosynthetically Active Radiation, averaged over experimental period) and total abundance of antheridia (gray data points and trend line) and oogonia (black) as encountered on final biomass samples in the top $15 \mathrm{~cm}$ of $C$. globularis. Curves represent non-parametric LOESS regression lines (Epanechnikov kernel, fitted based on $75 \%$ of points)

within the upper layer of $C$. globularis in open plots. In any case, charophycean species are known to react differently to environmental stress (Rubio et al., 2015; Rojo et al., 2017), so vegetative changes seen in our experiment are unlikely to be generic.

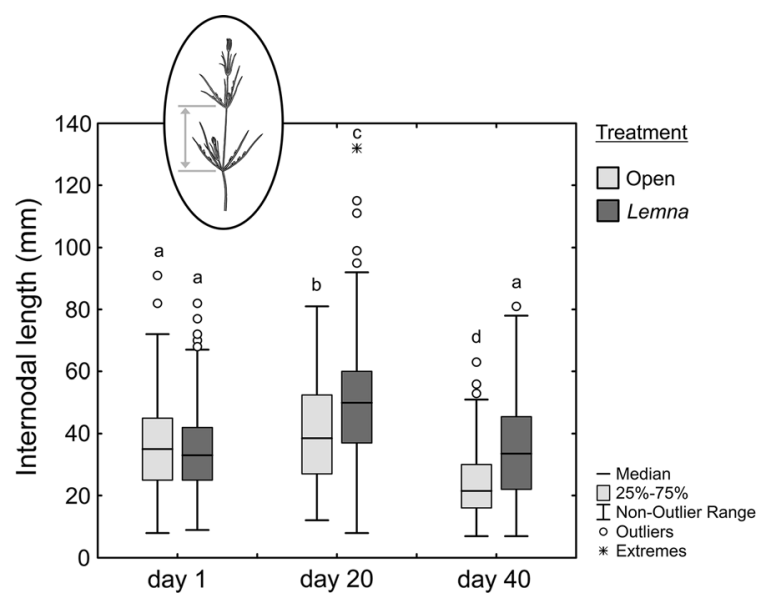

Fig. 6 Evolution of internodal length in open and Lemnacovered mesocosm plots ( $n=8$ per treatment and campaign). Different letters correspond to significant differences over all box plots

Gametangia densities diverged strikingly between both treatments. The quantity of antheridia and oogonia per biomass unit dropped markedly under shaded conditions, while in open plots reproductive investment instead evolved positively. This is in accordance with Asaeda et al. (2007), who found decreased sexual reproduction in deeper waters compared to shallow sites for Chara fibrosa var. fibrosa (A. Braun) and Nitella hyalina (De Candolle) C. Agardh, but contrasts to reports on Chara aspera C.L. 


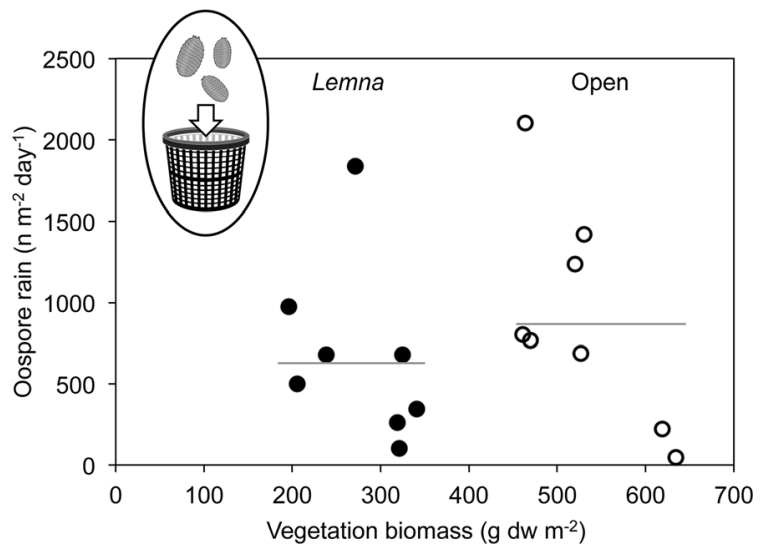

Fig. 7 Oospore deposition rate measured at the end of the experiment, in function of $C$. globularis biomass and treatment (open versus Lemna-covered). Gray lines: treatment means

Willdenow (no reproductive response to light manipulation; Blindow et al., 2003) and Chara braunii C.C. Gmelin (increased resource allocation toward sexual organs under light stress; Sato et al., 2014). Calero et al. (2015) noted that Chara hispida L. growing in deeper water took longer to develop mature gametangia and displayed lower reproductive vigor compared to individuals occurring at a shallower site. Possibly, different charophycean species cope with light or heat inhibition in different ways, although the range of irradiance (either controlled or fluctuating) can vary between studies. Inter- and intraspecific reproductive variability observed in submerged macrophytes could also be driven by phenological adaptations to changing environmental stability along a depth gradient, since deeper waters tend to be more stable and reliable when compared to more exposed shallow waters.

As with spacing between nodes, gametangia densities might have been influenced by biomass build-up near the water surface. Possibly, resources are allocated toward reproductive organs after a ceiling has been reached in terms of vertical growth. Still, compared to the starting situation-in which $C$. globularis did not yet fill the water column-densities of male and female reproductive structures decreased significantly in covered plots, indicating a true effect of Lemna cover. Increased reproductive effort and maturation of dormant oospores at decreasing water levels can also be an anticipation of drying-out of the habitat, as suggested for Chara australis R. Brown in Australia (Casanova, 1994). Hydroperiod duration could be a relevant factor even in temperate regions, in view of the pioneering strategy perfected by many Charophyceae.

When merging evolutions in biomass and gametangia densities, there was a clear correlation between irradiance (PAR) and total reproductive potential within the upper layer of $C$. globularis. Although accumulation of sufficiently warm days is required for the progression between phenological stages in Charophyceae (Calero et al., 2015), temperature differences in our study were small and insignificant, and therefore unlikely to be a prime factor explaining the decreased sexual productivity underneath Lemna. Detailed physiological studies need to be conducted in order to identify the ultimate trigger responsible for reproductive variability in $C$. globularis.

Oospore deposition did not follow clear trends of restrained reproductive capabilities in Lemna plots, probably because propagule traps were collected prior to full maturation and abscission of oospores. In addition, baskets installed in covered plots might have received an input of senescent thalli and attached oospores. Future research involving oospore trapping near the sediment should allow full realization of reproductive potential, by extending the collection period until complete die-off.

Taken together, negative effects on reproductive fitness of C. globularis can confidently be attributed to Lemna-induced stress, either directly through mechanisms inhibiting production of gametangia, or indirectly as a result of decelerated growth. Adding to decreased growth rates and gametangial densities, $C$. globularis might generate smaller oospores under light restriction (as seen in deeper water parts in a Polish lake; Boszke and Bociąg, 2010), further affecting reproductive potential. A decrease of reproductive output signifies a threat to survival of submerged macrophytes in ponds, ditches or sheltered areas of lakes overgrown by duckweeds, and will strengthen the likelihood of annual floating plant domination. Within this equilibrium, repeated cycles of recruitment in dark conditions (de Winton et al., 2004) in parallel with poor propagule supply could lead to a net loss of oospores, deplete the sediment bank and eventually eliminate the species from the community. Though it is not as conspicuous as a crash of standing vegetation, progressive erosion of the propagule bank will undermine the regenerative capacity and resilience of submerged macrophyte communities (Van Onsem and Triest, 2018). 
Breaking this vicious circle in flow-through systems might involve an engineered reduction of retention time or removal of obstacles near the overflow, allowing sustained, passive removal of floating plants. Similarly to the restoration of turbid waterbodies, phosphorus and/or nitrogen reduction alone needs to be quite drastic in order to manage a shift toward an equilibrium dominated by submerged macrophytes, due to hysteresis (Scheffer et al., 2003). Although active summer removal of floating mats might not be an ideal solution if propagule banks are in a depauperate state (van Zuidam et al., 2012), this particular type of management could stimulate reproductive output in already established submerged vegetation, as our results demonstrate. Care should be taken, however, when extrapolating reproductive responses to deeper water populations.

\section{Conclusion}

Complete cover by L. minor induced clear changes in growth strategy and reproductive abilities of $C$. globularis. Total biomass decreased, thallus internodes elongated and male and female gametangial densities dropped markedly relative to unstressed individuals. In shallow water, sufficient light penetration allows $C$. globularis to reach the surface, shorten internodes and increase reproductive investment. Duckweed mats therefore reduce the ability of $C$. globularis to maximize reproductive output, potentially leading to a gradual decline of the population. Since floating plants are expected to dominate more often in the wake of global warming, cutting back eutrophication becomes increasingly urgent to conserve reproductive abilities of submerged aquatic vegetation.

Acknowledgements The authors wish to thank Brussels Environment for allowing access to the study site.

Funding The authors did not receive support from any organization for the submitted work.

Data availability The datasets generated or analyzed during the current study are available from the corresponding author on simple request.

\section{Declarations}

Conflict of interest The authors declare no conflicts of interest.

Open Access This article is licensed under a Creative Commons Attribution 4.0 International License, which permits use, sharing, adaptation, distribution and reproduction in any medium or format, as long as you give appropriate credit to the original author(s) and the source, provide a link to the Creative Commons licence, and indicate if changes were made. The images or other third party material in this article are included in the article's Creative Commons licence, unless indicated otherwise in a credit line to the material. If material is not included in the article's Creative Commons licence and your intended use is not permitted by statutory regulation or exceeds the permitted use, you will need to obtain permission directly from the copyright holder. To view a copy of this licence, visit http://creativecommons.org/licenses/by/4.0/.

\section{References}

Asaeda, T., L. Rajapakse \& B. Sanderson, 2007. Morphological and reproductive acclimations to growth of two charophyte species in shallow and deep water. Aquatic Botany 86(4): 393-401.

Berger, J. \& M. Schagerl, 2004. Allelopathic activity of Characeae. Biologia 59(1): 9-15.

Blindow, I., A. Hargeby \& S. Hilt, 2014. Facilitation of clearwater conditions in shallow lakes by macrophytes: differences between charophyte and angiosperm dominance. Hydrobiologia 737(1): 99-110.

Blindow, I., J. Dietrich, N. Mollmann \& H. Schubert, 2003. Growth, photosynthesis and fertility of Chara aspera under different light and salinity conditions. Aquatic Botany 76(3): 213-234.

Boedeltje, G., A. J. R. Smolders, L. P. M. Lamers \& J. G. M. Roelofs, 2005. Interactions between sediment propagule banks and sediment nutrient fluxes explain floating plant dominance in stagnant shallow waters. Archiv Fur Hydrobiologie 162(3): 349-362.

Boedeltje, G., W. A. Ozinga \& A. Prinzing, 2008. The trade-off between vegetative and generative reproduction among angiosperms influences regional hydrochorous propagule pressure. Global Ecology and Biogeography 17(1): 50-58.

Bonis, A. \& P. Grillas, 2002. Deposition, germination and spatio-temporal patterns of charophyte propagule banks: a review. Aquatic Botany 72(3-4): 235-248.

Boszke, P. \& K. Bociagg, 2010. Preliminary analysis of the morphology and morphometry of Chara globularis Thuillier (Charophyta) oospores from Poland. Cryptogamie Algologie 31(2): 221-228.

Calero, S., W. Colom \& M. A. Rodrigo, 2015. The phenology of wetland submerged macrophytes related to environmental factors. Limnetica 34(2): 425-437.

Calero, S., D. A. Joye, A. Rey-Boissezon \& M. A. Rodrigo, 2017. Time and heat for sexual reproduction: comparing 
the phenology of Chara hispida of two populations at different latitudes. Aquatic Botany 136: 71-81.

Casanova, M. T., 1994. Vegetative and reproductive responses of charophytes to water-level fluctuations in permanent and temporary wetlands in Australia. Australian Journal of Marine and Freshwater Research 45(8): 1409-1419.

Chen, J., W. Ren, Q. Chou, H. Su, L. Ni, M. Zhang, Z. Liu \& P. Xie, 2020. Alterations in biomass allocation indicate the adaptation of submersed macrophytes to low-light stress. Ecological Indicators 113.

de Winton, M. D., M. T. Casanova \& J. S. Clayton, 2004. Charophyte germination and establishment under low irradiance. Aquatic Botany 79(2): 175-187.

DeWitt, T. J., A. Sih \& D. S. Wilson, 1998. Costs and limits of phenotypic plasticity. Trends in Ecology \& Evolution 13(2): 77-81.

Eckert, C. G., M. E. Dorken \& S. C. H. Barrett, 2016. Ecological and evolutionary consequences of sexual and clonal reproduction in aquatic plants. Aquatic Botany 135: 46-61.

Feuchtmayr, H., R. Moran, K. Hatton, L. Connor, T. Heyes, B. Moss, I. Harvey \& D. Atkinson, 2009. Global warming and eutrophication: effects on water chemistry and autotrophic communities in experimental hypertrophic shallow lake mesocosms. Journal of Applied Ecology 46(3): 713-723.

Garbey, C., G. Thiebaut \& S. Muller, 2004. Morphological plasticity of a spreading aquatic macrophyte, Ranunculus peltatus, in response to environmental variables. Plant Ecology 173(1): 125-137.

Haas, J. N., 1994. First identification key for charophyte oospores from Central-Europe. European Journal of Phycology 29(4): 227-235.

Hilt, S. \& E. M. Gross, 2008. Can allelopathically active submerged macrophytes stabilise clear-water states in shallow lakes? Basic and Applied Ecology 9(4): 422-432.

Janes, R. A., J. W. Eaton \& K. Hardwick, 1996. The effects of floating mats of Azolla filiculoides Lam and Lemna minuta Kunth on the growth of submerged macrophytes. Hydrobiologia 340(1-3): 23-26.

Janse, J. H. \& P. Van Puijenbroek, 1998. Effects of eutrophication in drainage ditches. Environmental Pollution 102: 547-552.

Kim, J.Y. \& J. Nishihiro, 2020. Responses of lake macrophyte species and functional traits to climate and land use changes. Science of the Total Environment 736.

Li, H. L., Y. S. Xu, Y. Y. Wang, N. Q. Yu, M. X. Zhang, G. C. Lei \& F. H. Yu, 2015. Does clonal fragmentation of the floating plant Eichhornia crassipes affect the growth of submerged macrophyte communities? Folia Geobotanica 50(3): 283-291.

Lu, J., Z. Wang, W. Xing \& G. Liu, 2013. Effects of substrate and shading on the growth of two submerged macrophytes. Hydrobiologia 700: 157-167.

Magnusson, A., H. Skaug, A. Nielsen, C. Berg, K. Kristensen, M. Maechler, K. van Bentham, B. Bolker \& M. Brooks, 2017. glmmTMB: Generalized Linear Mixed Models using Template Model Builder. R package version 0.1.1. http:// CRAN.R-project.org/package=glmmTMB.

Netten, J. J., G. H. Arts, R. Gylstra, E. H. van Nes, M. Scheffer \& R. M. Roijackers, 2010. Effect of temperature and nutrients on the competition between free-floating Salvinia natans and submerged Elodea nuttallii in mesocosms. Fundamental and Applied Limnology 177: 125-132.

Peeters, E., J. P. van Zuidam, B. G. van Zuidam, E. H. Van Nes, S. Kosten, P. G. M. Heuts, R. M. M. Roijackers, J. J. C. Netten \& M. Scheffer, 2013. Changing weather conditions and floating plants in temperate drainage ditches. Journal of Applied Ecology 50(3): 585-593.

Phillips, G., N. Willby \& B. Moss, 2016. Submerged macrophyte decline in shallow lakes: what have we learnt in the last forty years? Aquatic Botany 135: 37-45.

Portielje, R. \& R. M. M. Roijackers, 1995. Primary succession of aquatic macrophytes in experimental ditches in relation to nutrient input. Aquatic Botany 50(2): 127-140.

Puijalon, S., F. Piola \& G. Bornette, 2008. Abiotic stresses increase plant regeneration ability. Evolutionary Ecology 22(4): 493-506.

Rojo, C., M. Carramiñana, D. Cócera, G. P. Roberts, E. Puche, S. Calero \& M. A. Rodrigo, 2017. Different responses of coexisting Chara species to foreseeable Mediterranean temperature and salinity increases. Aquatic Botany 138: 53-63.

Rubio, F., C. Rojo, E. Núñez-Olivera \& M. A. Rodrigo, 2015. Effects of UVB radiation exposure from the molecular to the organism level in macrophytes from shallow Mediterranean habitats. Aquatic Botany 120: 112-120.

Sato, M., H. Sakayama, M. Sato, M. Ito \& H. Sekimoto, 2014. Characterization of sexual reproductive processes in Chara braunii (Charales, Charophyceae). Phycological Research 62(3): 214-221.

Schaible, R., A. Gerloff-Elias, F. Colchero \& H. Schubert, 2012. Two parthenogenetic populations of Chara canescens differ in their capacity to acclimate to irradiance and salinity. Oecologia 168(2): 343-353.

Scheffer, M., S. H. Hosper, M. L. Meijer, B. Moss \& E. Jeppesen, 1993. Alternative equilibria in shallow lakes. Trends in Ecology \& Evolution 8(8): 275-279.

Scheffer, M., S. Szabo, A. Gragnani, E. H. van Nes, S. Rinaldi, N. Kautsky, J. Norberg, R. M. M. Roijackers \& R. J. M. Franken, 2003. Floating plant dominance as a stable state. Proceedings of the National Academy of Sciences of the United States of America 100(7): 4040-4045.

Schneider, S. C., D. E. Pichler, T. Andersen \& A. Melzer, 2015. Light acclimation in submerged macrophytes: the roles of plant elongation, pigmentation and branch orientation differ among Chara species. Aquatic Botany 120: 121-128.

Soulié-Märsche, I. \& A. García, 2015. Gyrogonites and oospores, complementary viewpoints to improve the study of the charophytes (Charales). Aquatic Botany 120: 7-17.

Sultan, S. E., 2000. Phenotypic plasticity for plant development, function and life history. Trends in Plant Science 5(12): 537-542.

Van Drunen, W. E. \& M. E. Dorken, 2012. Trade-offs between clonal and sexual reproduction in Sagittaria latifolia (Alismataceae) scale up to affect the fitness of entire clones. New Phytologist 196(2): 606-616.

Van Onsem, S. \& L. Triest, 2018. Turbidity, waterfowl herbivory, and propagule banks shape submerged aquatic vegetation in ponds. Frontiers in Plant Science 9: 58-75.

Van Onsem, S., J. Rops \& L. Triest, 2018. Submerged seed, turion and oospore rain: a trap quantifying propagule 
deposition under aquatic vegetation. Aquatic Botany 145: 21-28.

van Zuidam, J. P., E. P. Raaphorst \& E. Peeters, 2012. The role of propagule banks from drainage ditches dominated by free-floating or submerged plants in vegetation restoration. Restoration Ecology 20(3): 416-425.
Publisher's Note Springer Nature remains neutral with regard to jurisdictional claims in published maps and institutional affiliations. 